\title{
MHC class II deficiency in the Dene native population: a case report highlighting pitfalls in diagnosis and treatment
}

\author{
Alex Lyttle ${ }^{1 *}$, Chaim Roifman², Harjit Dadi ${ }^{2}$, Nicola Wright ${ }^{1}$, Fotini Kavadas ${ }^{1}$ \\ From Canadian Society of Allergy and Clinical Immunology Annual Scientific Meeting 2013 \\ Toronto, Canada. 3-6 October 2013
}

\section{Background}

Bare lymphocyte syndrome (BLS) is a rare, hereditary immunodeficiency characterized by the absence of major histocompatibility complex (MHC) class II leading to a form of severe combined immunodeficiency (SCID). Here we present a case introducing BLS in a novel population and emphasize some of the difficulties faced in diagnosing and treating this condition.

\section{Case}

Our patient was a male of Dene native background from the Northwest Territories of Canada. Between the ages of 2 weeks to 6 months of age he had multiple bouts of both viral and bacterial pneumonia, two episodes of bacteremia, and showed poor growth. Despite a low lymphocyte count of $0.9 \times 10^{9}$ cells/L and undetectable immunoglobulins, an immunologist was not initially consulted.

Finally, after his fifth episode of pneumonia he was referred to the Immunology Department in Edmonton and then transferred to the Alberta Children's Hospital in Calgary. Initial testing revealed IgG levels $<2$ g/L, undetectable IgM/IgA and poor response to the diphtheria and tetanus vaccines. Flow cytometry revealed low CD3, CD4 and CD19 counts but normal NK and CD8 counts. Thymidine mitogen testing for $\mathrm{T}$-cell function was low however T-cell receptor excision circle (TREC) analysis was normal. An open thymic biopsy showed evidence of $\mathrm{CD} 4+$ maturation arrest. Based on this, MHC class II expression was investigated looking for HLA-DR proteins by flow cytometry and were found to be absent.

A suitable bone marrow donor could not be found. Due to the patient's deteriorating course, a high resolution

\footnotetext{
* Correspondence: alex.lyttle@gmail.com

'Alberta Children's Hospital, Calgary, Alberta, Canada

Full list of author information is available at the end of the article
}

hematopoietic stem cell transplantation using a $5 / 6$ umbilical cord donor was performed. Unfortunately, engraftment failed and the child passed away at 19 months of age secondary to respiratory failure.

The genetic testing came back posthumously showing MHC class II deficiency with a RFX5 gene mutation (R400X (1198 c >t).

\section{Discussion}

BLS is extremely rare with less than 200 reported cases worldwide [1] and can result from mutations in one of four regulatory proteins necessary for MHC-II production: CIITA, RFX5, RFXANK and RFXAP [2]. This condition leads to severe CD4+ T-cell dysfunction and thus recurrent bacterial, viral and protozoal infections. Recently TREC studies have begun to be used as part of newborn screening programs for SCID. While sensitive for nearly all forms of SCID [3,4], TREC studies may be normal in BLS [5].

Our case is the first of BLS identified in the Dene native population. Given that early BMT has been shown to have better success rates in treating BLS [6], a screening program may be beneficial in this population.

\section{Acknowledgments}

The authors of this paper thank the immunology laboratory at The Hospital for Sick Children in Toronto for their assistance with the diagnostic work-up of this patient. We also thank Dr. Capucine Picard at Centre d'etude des deficits immunitares, Paris, France for her contribution in the genetic analysis of this patient.

\section{Disclosure}

No outside sources of funding were used in the creation of this abstract.

\section{Authors' details}

${ }^{1}$ Alberta Children's Hospital, Calgary, Alberta, Canada. ${ }^{2}$ The Hospital for Sick Children, Toronto, Ontario, Canada. 


\section{References}

1. Ouederni, et al: Major histocompatibility class II expression deficiency caused by RFXANK founder mutation: a survey of 35 patients. Blood 2011, 118(19):5108-18.

2. Krawczyk M, Reith W: Regulation of MHC class II expression, a unique regulatory system identified by the study of primary immunodeficiency disease. Tissue Antigens 2006, 67:183-197.

3. Somech, et al: T-cell receptor excision circles in primary immunodeficiencies and other T-cell immune disorders. Curr opinion Allergy Clin Immunol 2011, 11:517-524.

4. Puck, et al: Neonatal screening for severe combined immunodeficiency. Curr Opin Pediatr 2011, 23:667-673.

5. Lev, et al: Thymic function in MHC class II-deficiency patients. Journal of Allergy and Clinical Immunology 2012.

6. Siepermann et al: MHC class II deficiency cured by unrelated mismatched umbilical cord blood transplantation: case report and review of 68 cases in the literature. Pediatric Transplantation 2011, 15(4):E80-6.

doi:10.1186/1710-1492-10-S1-A1

Cite this article as: Lyttle et al:: MHC class II deficiency in the Dene native population: a case report highlighting pitfalls in diagnosis and treatment. Allergy, Asthma \& Clinical Immunology 2014 10(Suppl 1):A1.

\section{Submit your next manuscript to BioMed Central} and take full advantage of:

- Convenient online submission

- Thorough peer review

- No space constraints or color figure charges

- Immediate publication on acceptance

- Inclusion in PubMed, CAS, Scopus and Google Scholar

- Research which is freely available for redistribution

Submit your manuscript at www.biomedcentral.com/submit 